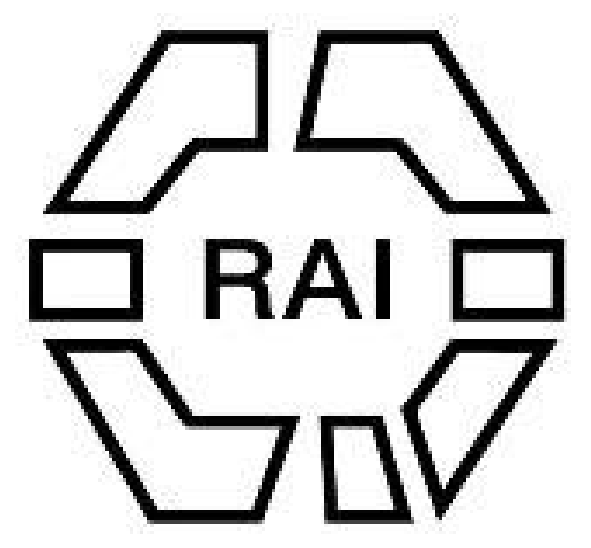

\title{
WILEY
}

\section{Ancestor-Worship in Japan.}

\section{Author(s): W. G. Aston}

Source: Man, Vol. 6 (1906), pp. 35-37

Published by: Royal Anthropological Institute of Great Britain and Ireland Stable URL: http://www.jstor.org/stable/2788694

Accessed: 27-06-2016 04:36 UTC

Your use of the JSTOR archive indicates your acceptance of the Terms \& Conditions of Use, available at

http://about.jstor.org/terms

JSTOR is a not-for-profit service that helps scholars, researchers, and students discover, use, and build upon a wide range of content in a trusted digital archive. We use information technology and tools to increase productivity and facilitate new forms of scholarship. For more information about JSTOR, please contact support@jstor.org.

Royal Anthropological Institute of Great Britain and Ireland, Wiley are collaborating with JSTOR to digitize, preserve and extend access to Man 
stout post, in which case it was a cruel performance, as men stood round and beat the animal when it moved. Little mercy is shown to the animals at any time, as can be shown by the Naples Society for the Protection of Animals, which has 10,000 iron instruments of torture which have been confiscated by their inspectors. Iron bands with teeth (Fig. 5) are fastened on the foreheads of oxen; a slight pulling of ropes attached to these plates drives the saw-like teeth into the flesh.

Great cruelty is still to be seen in central and southern Italy - probably a survival of barbaric times. The peasants do not realise that animals can suffer. When remonstrated with they generally say, "Non è cristiano" - "What matter ; it's only an animal."

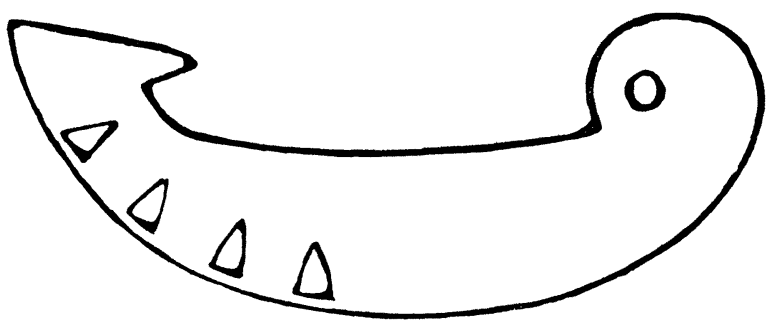

FIG. 4.-ENGLISH OX-SHOE.

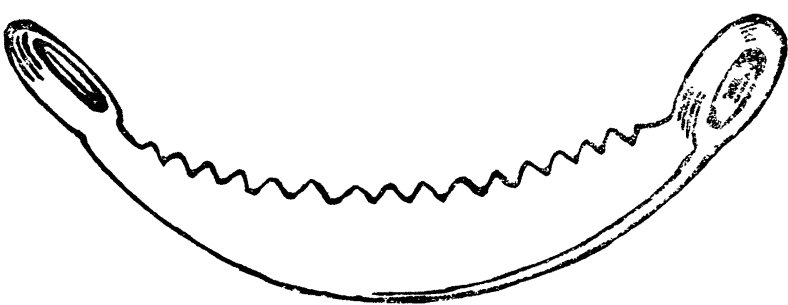

FIG. 5.-IRON BAND WITH TEETH.

\section{Religion : Japan.}

C. J. PR ÆTORIUS.

\section{Ancestor-worship in Japan. By W. G. Aston.}

Both "ancestor" and "worship" are ambiguous terms. The ancestor may 23 be the ancestor of the individual or a deceased forefather of the race. In the latter case, it would perhaps be better to use some such word as hero worship. The mere racial ancestor is worshipped not qua ancestor but for his services or merits, real or supposed. Worship may be of a mere man, alive or dead, in which case it is not religion, or of a deity.

Shinto, the old native religion of Japan, had no cult of true ancestors, whether of the individual or of the race. The greater gods are not deified human beings but nature deities, as the sun, the moon, the wind, the rainstorm, the earth, the process of growth, \&c. Even the minor Kami, when not themselves obviously elemental deities are for the most part satellites or children of gods of this class though some are at the same time deified types of classes of human beings. There is no clear case of a deified individual man. An official collection of prayers and other religious formulæ made early in the tenth century contains none addressed to true aucestors and makes no reference to a continued life after death. Shinto had no funeral service, that which is now so called being an innovation dating from 1868. It would have been inexpressibly shocking to an ancient Japanese to see a Shinto priest take part in any ceremonial connected with death. The iustitution of adoption, so common in modern Japan, was unknown in ancient times. As this custom had for its chief object the maintenance of the worship of the ancestors of the family, its absence from ancient Shinto has a significance which will be readily recognised.

Whence, therefore, comes the widespread belief, not only in Japan but even in this country, that Shinto is or is based on ancestor worship? In Japan and, China Captain Brinkley says: "Ancestor-worship was the basis of Shinto. The divinities, whether " celestial or terrestrial, were the progenitors of the nation, from the Sovereign and the " princes surrounding the throne to the nobles who discharged the services of the State 
"and the soldiers who fought its battles." Let us examine first the case of the Sovereign viz., the descent of the Mikados from Amaterasu. It is this to which reference is made in the Times and in Reuter's telegrams when the latter is called "the first Imperial Ancestor" and when the Mikado's visit to Ise last autumn is spoken of as ancestorworship. Now Amaterasu (the Heaven shining one) is at one time the Sun itself, and at another, by a confusion of ideas familiar to mythologists, an anthropomorphic goddess. She is also called Hirume or the Sun-female, and Hi no Kami, the deity of the Sun. She has for brothers the Moon-Grod, the Rain-Storm, the Wind, and other unmistakeable nature deities. The genealogy which traces the Mikado's descent from her covers a period of some 2,000,000 years, and includes such incidents as the producing of cbildren by crunching jewels in the mouth and spurting out the fragments. Yet this is what we are asked to believe when we are told that Shinto is ancestor-worship. It is true that there are Euhemerists in Japan who try to make out that Amaterasu was a mortal Empress who lived in a place on earth called Takama no hara (the Plain of High Heaven) and talk of the "principles of rice-culture and weaving" being known in her reign. Motoöri, the greatest Shinto theologian, treats such speculations with utter contempt. We may well follow his example.

The Mikados were not the only Japanese who claimed descent from deities. All the great Houses who constituted the hereditary governing caste in ancient times had their ujigami (surname or House deity) to whom they devoted a special cult and from whom they were supposed to be descended. A work entitled Shojiroku, compiled in 815, traces the descent of a large number of these families from ancestors who generally turn out, upon examination, to be nature-gods or their children or satellites. Among them are the Rain storm (or the Rain-storm God) the Sea God, the God of Growth, the Yatagarasu or Sun-crow, a three-legged bird of a red colour which inhabits the sun, and the chief officials of the Court of the Sun-goddess.

Clearly these are not true ancestors. In the worls of Dr. E. Caird, " it is not that " the being worshipped is conceived of as a Grod because he is an ancestor but rather " that he is conceived as an ancestor because he is believed to be their God." Still there may be real ancestors among the obscurer personages of the old genealogies, though of subordinate importance and of later date. Take, for example, Nigi-haya-hi, ancestor of the Mononobe House, a chieftain of one of the Yamato tribes subdued by Jimmu Tenno. $\mathrm{He}$ is described as a child of the Heavenly Deity who came down from heaven riding in a heavenly Rock-boat. This, with his name which means "Mild-swift-sun" and the analogy of Amaterasu and the Mikados suggests that he was the Sun-deity of the tribe. On the other hand, it is possible that we have here a case of what Herbert Spencer calls "complimentary naming after the Sun," of which examples are not lacking in Japanese legend and history.

The older Shinto has little or no trace of genuine ancestor-worship. In the Nihongi there are one or two isolated cases of "worship" being paid by Mikados to recently deceased parents or forefathers, but there is nothing to show that it had a religious character. They had apparently no shrines and their was no regular cult in their honour. It is not until the ninth century that cases begin to occur of norito (prayers) of a distinctly religious character being addressed to deceased Mikados. The deification of deceased heroes dates from about the same period. The worship of his ancestors by the Mikado is at the present day an established Court ceremonial, and the offerings at their tombs have been assimilated to those made at the shrines of nature-deities. In all this I strongly suspect Chinese influence.

Early in the nineteenth century, the Shinto theologian Hirata made an at tempt to introduce a general cult of real ancestors on the Chinese model. He instructed his disciples to address prayers to their ancestors of every generation from the parents of the worshipper up to the "Great Ancestor," the founder of the family. Their spirits 
are to be adjured to avert evil from their descendants and to grant them prosperity and long life. Chinese (and Buddhist) influences are also responsible for the Shokonsha (shrine for calling upon souls) erected at Tokio soon after the restoration of 1868 . Here periodical memorial services are held in honour of departed soldiers and others who have done good service to their country.

The views expressed in this paper are in substantial agreement with those of Dr. Florenz, the principal German authority on the subject. (See his Japanische Mythologie, p. 253.)

W. G. ASTON.

Craniology : Trephining.

Seligmann.

Note on a Trephined skull from Now Britain. By C. G. 24
Seligmann, M.B.

The trephined skull of which a photograph is reproduced in the figure is one of a number of skulls given me in New Britain by Mr. R. Parkinson, who stated that they had been collected from the bush in the neigh bou rhood of Blanche Bay. Uufortunately the skull figured was given me packed with a n u m ber of others so that no opportunity arose of discussing the trephine hole or its purpose with Mr. Parkinson ; indeed, I did not know that his gift included a trephined s kull until it was unpacked in this country. That

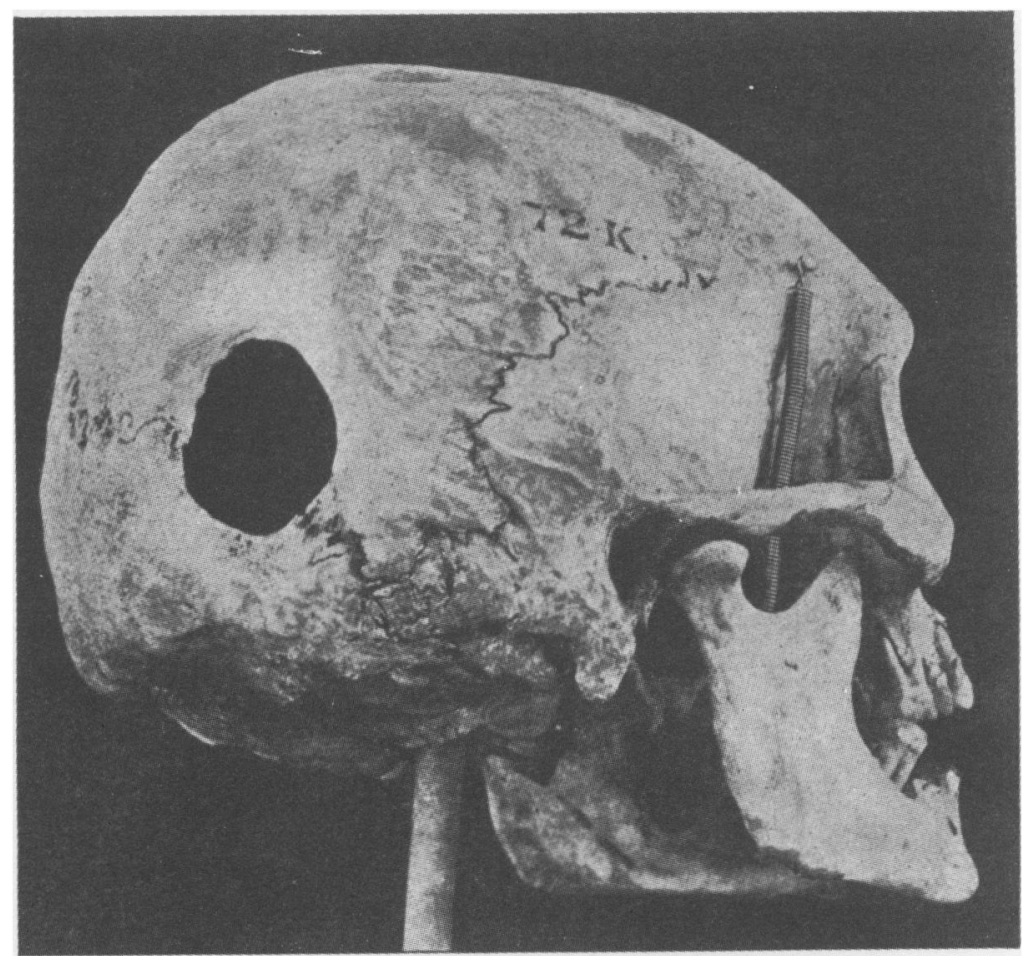
the skull had been exposed in the bush for some time was evident from the fact that vegetable roots and tendrils had grown through most of the foramina.

In the right occipital region is an oval aperture measuring in chief vertical diameter $2 \cdot 8 \mathrm{~cm}$. and in smaller transverse diameter $2 \cdot 2 \mathrm{~cm}$.

It involves part of the posterior border of the right parietal, about midway between the superior and inferior angles, and part of the adjacent portion of the occipital squama. In the latter position it lies altogether above the superior curved line. With the excep. tion of a minute lenticular osteoma on the left parietal bone, about $1 \mathrm{~cm}$. from the sagittal suture and $4 \cdot 5 \mathrm{~cm}$. in front of the lambda, there is no sign of disease.

The edge of the aperture shelves regularly from the outer towards the inner aspect of the bone, the edge of the border of the opening being sharp and well defined.

$$
\text { [. } 37 \text { ] }
$$

